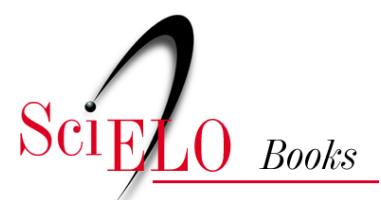

\title{
34. A Vida Breve de Alguns Personagens Famosos da História da Medicina
}

\author{
Joffre Marcondes de Rezende
}

\section{SciELO Books / SciELO Livros / SciELO Libros}

REZENDE, J. M. A Vida Breve de Alguns Personagens Famosos da História da Medicina. In: À sombra do plátano: crônicas de história da medicina [online]. São Paulo: Editora Unifesp, 2009, pp. 273-280. História da Medicina series, vol. 2. ISBN 978-85-61673-63-5. https://doi.org/10.7476/9788561673635.0035.

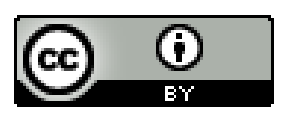

All the contents of this work, except where otherwise noted, is licensed under a Creative Commons Attribution 4.0 International license.

Todo o conteúdo deste trabalho, exceto quando houver ressalva, é publicado sob a licença Creative Commons Atribição 4.0.

Todo el contenido de esta obra, excepto donde se indique lo contrario, está bajo licencia de la licencia Creative Commons Reconocimento 4.0. 


\section{A Vida Breve de Alguns Personagens Famosos da História da Medicina}

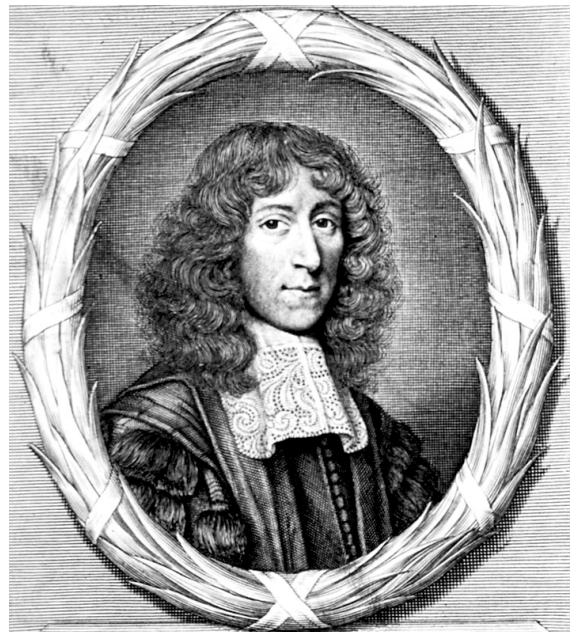

John Mayow (I643-I679).

Ta memória da medicina encontramos exemplos de médicos e cientistas que tiveram uma curta existência e que, apesar disso, deixaram seus nomes inscritos na história da medicina pelo que lograram realizar.

Escolhemos como exemplos personagens que não chegaram a ultrapassar quarenta anos de idade e que tiveram ideias inovadoras, fizeram descobertas importantes, trabalharam arduamente, publicaram obras notáveis ou lutaram com determinação contra a inércia da ciência oficial de sua época.

Vejamos de modo resumido a vida e a obra de alguns deles.

\section{Jacob Bontius (I592-I63I)}

Médico holandês, faleceu aos 39 anos. Estudou em Leyden, recebendo o grau de médico em r6I4. Em I627 ingressou na Companhia das Índias e foi enviado à Batávia. Seus conhecimentos de medicina tropical eram precários e em apenas quatro anos em Java descreveu várias doenças encontradas na colônia holandesa, inclusive o beribéri, assim como a flora e 
a fauna da região. Sua obra principal De Medicina Indorum foi publicada por seu irmão William Bontius sete anos após a sua morte (Andrade e Duarte, 1956, p. 356).

\section{Regnier de Graaf (I64I-I673)}

Médico holandês, faleceu aos 32 anos. Ainda como estudante, foi o primeiro a obter a secreção pancreática. Através da abertura do duodeno de um cão, conseguiu cateterizar o ducto de Wirsung com a haste oca de uma pena e obteve suco pancreático puro. Até então desconhecia-se a função do pâncreas, considerado como um apoio para o estômago ou um órgão de convergência de vasos quilíferos. A experiência de Graaf da fístula pancreática só foi repetida por Claude Bernard no século XIx. Estudou posteriormente com detalhes a anatomia dos órgãos sexuais masculinos e femininos e descreveu o fenômeno da ovulação e os folículos ovarianos que contêm os óvulos em fase de maturação, hoje conhecidos como folículos de Graaf, conforme a denominação dada por Haller em I730. Deixou ainda um tratado sobre clisteres, método terapêutico muito empregado na época (Major, I954, pp. 580-582).

$$
\text { John Mayow (I 643-I 679) }
$$

Físico inglês, faleceu aos 36 anos. Robert Boyle, físico inglês de quem Mayow fora discípulo, havia demonstrado que uma vela se apaga e que um camundongo morre na ausência do ar atmosférico.

Admitia-se que o ar atmosférico continha dois componentes importantes: o "ar do fogo" e o "ar vital". Mayow colocou sob a mesma campânula uma vela acesa e um camundongo e verificou que ambos os fatos ocorriam na metade do tempo, o que demonstrava que o "ar do fogo" e o "ar vital” eram um só e único componente gasoso do ar atmosférico. Mayow foi o primeiro a compreender o mecanismo da respiração e a combater a teoria de que o ar inspirado destinava-se a refrigerar o coração. Atribuiu a cor mais vermelha do sangue arterial ao seu maior conteúdo em "ar do fogo". Seus trabalhos foram simplesmente ignorados pelos seus contemporâneos (Fahraeus, I956, pp. 580-582). 


\section{Giorgio Baglivi (I668-1707)}

Médico italiano, faleceu aos 39 anos. Foi um dos criadores da escola iatrofísica, segundo a qual o organismo humano poderia ser esquematizado com base em modelos mecânicos. Assim, o coração poderia ser comparado a uma bomba, o pulmão a um fole, os músculos a alavancas, a mucosa intestinal a peneiras e assim por diante. Considerava, entretanto, a iatrofísica como especulação teórica sem aplicação na prática médica. Era um clínico brilhante e seguia a medicina hipocrática. Dizia que não havia livro mais sábio do que o próprio enfermo e que aquele que sabe diagnosticar sabe tratar (Major, op. cit., pp. 506-507).

\section{François Xavier Bichat (I77I-I802)}

Médico francês, faleceu aos 3 I anos. Estudou em Montpellier, Lyon e Paris e foi médico do Hôtel-Dieu nos dois últimos anos de sua vida. Profundamente interessado nos problemas da vida e da morte, realizou mais de seiscentas autópsias e chegava a passar a noite junto dos cadáveres. Escreveu um tratado de anatomia descritiva denominado Anatomie génerale appliquée à la physiologie, em quatro volumes, no qual lançou a ideia dos tecidos na formação dos órgãos. Seu livro Recherches physiologiques sur la vie et la mort teve várias edições e contém um grande número de observações fisiológicas e patológicas (Idem, p. 650). No prefácio da quinta edição, publicado em I 829, assim se expressou Magendie referindo-se à Bichat: "Son esprit observateur, son génie experimental, sa manière lucide de présenter les faits expliquent la grande influence que ce livre a exercé sur l'esprit des physiologistes et des médecins" (Magendie, I 829, pp. I-5).

\section{Henry Hill Hickman (I800-1830)}

Médico inglês, faleceu aos trinta anos incompletos. Desde os tempos de estudante em Edimburgo, Hickman não se conformava com o sofrimento dos doentes durante as intervenções cirúrgicas. Vivia em Ludlow, onde realizou experiências em animais, operando-os sob a ação da inalação de gás carbônico $\left(\mathrm{CO}_{2}\right)$. Notou que os animais, sob a ação deste gás, não demonstravam 
sentir dor durante o ato cirúrgico e teve a ideia de usar o mesmo processo no homem. Para tanto, solicitou permissão à Royal Society, da qual faziam parte Davy e Faraday, que conheciam a ação do óxido nitroso. Foi nomeada uma comissão para apreciação do assunto e a autorização lhe foi negada.

Dirigiu-se, então, à Associação Médica de Londres, onde sua solicitação foi recebida com indiferença e ele foi considerado um visionário. Como última tentativa, escreveu ao rei Carlos x, da França, pedindo-lhe que desse a conhecer suas experiências à Academia de Paris. Em sessão especial em 28 de setembro de I 828, a Academia, com um único voto favorável do cirurgião Larrey, que servira no exército de Napoleão, pronunciou-se contra, considerando um crime expor o paciente a um risco adicional pela inalação de gás. Amargurado, Hickman voltou à Inglaterra e faleceu dois anos depois (Fülop-Miller, I95 I, pp. 85-97).

\section{Daniel Carrión (I859-1885)}

Doutorando de medicina em Lima, Peru, faleceu aos 26 anos. Duas doenças acometiam a população dos Andes peruanos e também do Equador e da Colômbia: a febre de Oroya e a verruga peruana. Havia dúvida se eram duas doenças independentes ou fases distintas de uma mesma enfermidade. Carrión, sextanista do curso médico, convenceu-se de que só havia um meio de resolver a questão: inocular o material da verruga em um voluntário sadio. Decidiu pela autoexperimentação e inoculou em si próprio o material colhido de um jovem que apresentava lesão característica da verruga peruana. Apresentou todos os sintomas da febre de Oroya e faleceu 39 dias após a autoinoculação.

Deste modo, com o sacrifício da própria vida, demonstrou que a febre de Oroya e a verruga peruana eram uma só doença. Em I895, Odriozola propôs para a doença o nome de doença de Carrión. Sua etiologia só foi descoberta em 1909 por outro médico peruano, Alberto Barton. O agente causal é uma bactéria que recebeu o nome de Bartonella baciliformis em homenagem ao seu descobridor. Na cidade de Lima há um monumento com a estátua de Daniel Carrión (Altman, I998, pp. 6-8). 


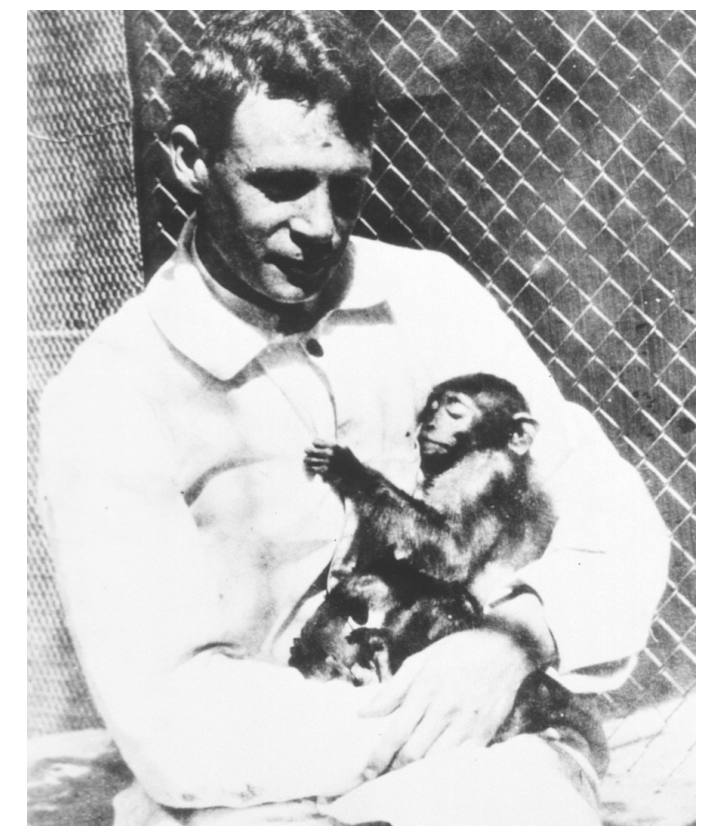

Ricketts teve seu nome imortalizado em um gênero de micro-organismos.

\section{Howard Taylor Ricketts (I87I-I9IO)}

Médico norte-americano, faleceu aos 39 anos. Graduou-se em medicina em I 897 e dedicou-se à dermatologia e microbiologia. Seus primeiros estudos referem-se à blastomicose causada pelo fungo Blastomyces dermatidis ou doença de Gilchrist. A fim de completar sua formação como pesquisador, estagiou na Inglaterra, na Alemanha e na França. Regressando aos Estados Unidos foi nomeado professor associado de patologia e bacteriologia da Universidade de Chicago. Em I 906 foi encarregado de estudar a febre maculosa das Montanhas Rochosas no estado de Montana, onde realizou simultaneamente trabalhos de campo e de laboratório. Descobriu que o transmissor da febre maculosa era uma espécie de carrapato e conseguiu reproduzir experimentalmente a infecção em macacos e cobaias.

Em 1909 anunciou a descoberta do micro-organismo causador da doença, que ele julgava fosse uma bactéria. Na mesma época foi ao México investigar o tifo epidêmico, ou tifo exantemático, doença semelhante à febre maculosa. Descobriu, com seu assistente Russell Wilder, que o agente etio- 
lógico se transmitia através do piolho (Pediculus corporis). Em 3 de março de r9 го faleceu na cidade do México, vítima do tifo exantemático (Weiss e Strauss, I99I, pp. I24I-I242). Seu nome foi imortalizado por Henrique da Rocha Lima que propôs o nome de Rickettsia para um novo gênero de micro-organismos intermediários entre as bactérias e os vírus. As doenças produzidas por Rickettsias denominam-se rickettsioses (Bacellar, I963, p. I82).

\section{Stanislau von Prowazek (I875-I9I5)}

Tal como Ricketts faleceu vitimado pelo tifo exantemático, quando contava 39 anos e três meses de idade. Natural de Böhmen, na Áustria, hoje parte da República Tcheca, tornou-se um bacteriologista e protozoologista de renome. Em I907 descreveu inclusões corpusculares nas células conjuntivais em casos de tracoma, admitindo acertadamente tratar-se de coleções de vírus recobertas por material oriundo das próprias células infectadas (Sebastian, I999, p. 602).

Trabalhando no Instituto de Medicina Tropical de Hamburgo, associou-se a Henrique da Rocha Lima nas pesquisas sobre o tifo exantemático. Sabia-se que o tifo era transmitido pelos piolhos e Prowazek inoculou em si próprio corpúsculos encontrados em piolhos para testar sua patogenicidade; adquiriu a infecção, da qual veio a falecer após três semanas, em fevereiro de I9I 5. Juntamente com Ricketts, foi homenageado por Rocha Lima na espécie prowazekii do gênero Rickettsia (Bacellar, op. cit., p. I82).

\section{Gaspar de Oliveira Vianna (I885-I9I4)}

Médico brasileiro, faleceu aos 29 anos. Natural do Pará, fez o curso de medicina na Faculdade Nacional de Medicina, do Rio de Janeiro. De uma inteligência brilhante, ainda como estudante destacou-se por seu interesse pela histologia. Sua tese de doutoramento versa sobre a estrutura da célula de Schwann dos vertebrados, um trabalho de histologia comparada.

Em I909, após a conclusão do curso médico, foi convidado por Oswaldo Cruz para integrar a equipe de Manguinhos como patologista. Uma de suas primeiras tarefas foi a de estudar a anatomia patológica da doença que Carlos Chagas acabara de descobrir em Minas Gerais - a tripanosomíase 
americana. Seus estudos sobre o ciclo do Trypanosoma cruzi e sua divisão intracelular se tornaram clássicos.

Da tripanosomíase passou à leishmaniose e em i9I I descreveu a Leishmania brasiliensis como espécie diferente da Leishmania tropica, causadora do botão do Oriente. Descobriu o tratamento da leishmaniose pelo tártaro emético em solução a I \% por via venosa, que era bem tolerada pelos pacientes. Verificou ainda que o tártaro emético tinha ação idêntica no calazar e no granuloma venéreo. Em I9 I4, faleceu de tuberculose miliar disseminada, que contraíra durante uma autópsia, tornando-se, ao mesmo tempo, mártir da ciência e benfeitor da humanidade (Idem, pp. 202-209).

\section{Rosalind Elsie Franklin (1920-1958)}

Faleceu aos 38 anos. Foi uma das mais brilhantes pesquisadoras inglesas do século xx. Formada em Físico-química em I94 I pela Universidade de Cambridge, dedicou-se aos estudos de cristalografia por raios-X. Realizou inicialmente pesquisas sobre o carvão, no esforço de guerra da Inglaterra na Segunda Guerra Mundial.

Após a guerra dedicou-se inteiramente ao estudo da estrutura do DNA trabalhando no King's College, de Londres. Esteve prestes a desvendar a estrutura do DNA e seus achados foram fundamentais para que Francis Crick e James Watson desenvolvessem o modelo de dupla hélice do DNA. Embora utilizando dados e fotografias de raios-X obtidos por Rosalind Franklin, Crick e Watson omitiram sua decisiva contribuição na elucidação do problema. Nos seus últimos anos de vida, Rosalind Franklin realizou pesquisas sobre o estrutura do RNA viral, as quais trouxeram novos e importantes conhecimentos no campo da biologia molecular. A descoberta da estrutura do DNA mereceu o prêmio Nobel em I962, tendo sido contemplados Francis Crick, James Watson e Maurice Wilkins. Rosalind Franklin, acometida por um câncer, havia falecido em I958. Em I968 Watson escreveu um livro The Double Helix, no qual admitiu ter utilizado os dados e fotografias não publicados de Rosalind Franklin, sem a sua permissão e sem o seu conhecimento. Esta revelação lançou uma sombra na história da mais importante descoberta do século xx e abalou o mérito de Francis Crick e James Watson (McGrayne, I995, pp. 317-344). 


\section{Referências Bibliográficas}

Altman, L. K. Who Goes First: The Story of Self-experimentation in Medicine. Berkeley, University of California Press, I998.

Andrade, G. O. \& Duarte, E. Morão, Rosa e Pimenta. Recife, Arquivo Público Estadual de Pemambuco, I956.

Bacellar, R. C. Brazil's Contribution to Tropical Medicine and Malaria. Rio de Janeiro, Gráfica Olímpica Editora, I963.

Fahraeus, R. Historia de la Medicina. Barcelona, Ed. Gustavo Gili, I956.

FAlCÃo, E. C. Opera Omnia de Gaspar Vianna. CNPq e outros, I962

Fülop-Miller, R. O Triunfo sobre a Dor. História da Anestesia. $2^{\mathrm{a}}$ ed., Rio de Janeiro, José Olympio, I95 I.

Magendie, F. “Prefácio”. In: Bichat, M. F. X. Recherches phyisiologiques sur la vie eat la mort, $5^{\text {a }}$ ed. Paris, Gobon-Béchet Jeune Lib., I 829.

Major, R. H. A History of Medicine. Oxford, Blackwell Scientific Publications, I954.

McGrayne, S. B. Mulheres que Ganharam o Prêmio Nobel em Ciências. São Paulo, Marco Zero, I995, pp. 317-344.

Morton, L. T. A Medical Bibliography (Garrison and Morton), $4^{\underline{a}}$ ed. Hampshire, I983.

Sebastian, A. A Dictionary of the History of Medicine. New York, The Parthenon Publishing Group, I999.

Weiss, E. \& Strauss, B. S. “The Life and Career of Howard Taylor Ricketts”. Reviews of Infectious Diseases, I3 (6), pp. I24I-I 242, I99I. 